\title{
THE CLASH OF RURAL AND URBAN VALUES IN THE COMIC BOOKS BUDAK KAMPUNG AND MAT SOM
}

\section{(Pertembungan Nilai Desa dan Kota dalam Buku Komik Budak Kampung dan Mat Som)}

Nurul Syazwani Mohd Dahalan

shazwanidahalan@gmail.com

Wan Hasmah Wan Teh*

hasmahwt@usm.my

School of Humanities, Universiti Sains Malaysia.

Published online: 1 December 2020

To Cite: Nurul Syazwani Mohd Dahalan and Wan Hasmah Wan Teh. (2020). The Clash of Rural and Urban Values in the Comic Books Budak Kampung and Mat Som. Malay Literature, 33(2), 212-242.

\begin{abstract}
Lat, whose real name is Mohammad Nor Khalid, is a distinguished and versatile figure among cartoonists in Malaysia. His comic books tend to record sociocultural issues in Malaysia and often show the realities of Malaysian life, especially that of the rural Malay community. Comics are not just reading material for entertainment but are also an important medium for conveying ideas, criticisms and insights as well as having the ability to expose various disparities in local communities. This paper will look into the clash of rural and urban values in two of Lat's comic books entitled Budak Kampung (1979) and Mat Som (1989). The objective of this paper is to analyse the clash of values between rural and urban communities and explain the use of comic elements in conveying meanings in both comics. This paper will use the theory of sociology of literature developed by Alan Swingewood (1972), which is a sociocultural approach to the production of literary works. The findings of this study show that Lat's childhood experiences influenced the creation of Budak Kampung, while his young adulthood experiences
\end{abstract}


influenced the creation of Mat Som. The clash of rural and urban values are tremendously significant in both works, as depicted by the entry of tin mining companies, selling of land, choosing a spouse, clothing styles and way of thinking.

Keywords: comic, clash of values, sociocultural influence, Budak Kampung, Mat Som

\begin{abstract}
Abstrak
Lat atau nama sebenarnya Mohammad Nor Khalid merupakan tokoh yang unggul dan serba boleh dalam kalangan kartunis di Malaysia. Karya komik beliau cenderung merakamkan isu berkaitan sosiobudaya masyarakat di Malaysia dan sering menampilkan kehidupan realiti rakyat Malaysia terutamanya masyarakat Melayu desa. Komik bukan sahaja bahan bacaan berbentuk hiburan tetapi juga merupakan medium penting untuk menyampaikan idea, kritikan, pandangan serta mampu mendedahkan pelbagai kepincangan dalam masyarakat setempat. Artikel ini ingin melihat pertembungan nilai desa dan kota dalam dua buah komik Lat bertajuk Budak Kampung (1979) dan Mat Som (1989). Objektif artikel ini adalah untuk menganalisis pertembungan nilai masyarakat desa dan kota serta menjelaskan penggunaan unsur komik dalam penyampaian makna dalam kedua-dua komik tersebut. Artikel ini akan menggunakan teori sosiologi sastera yang dikembangkan oleh Alan Swingewood (1972), iaitu pendekatan pengaruh sosiobudaya terhadap penghasilan karya sastera. Dapatan kajian mendapati pengalaman kehidupan Lat sewaktu kecil telah mempengaruhi penciptaan komik Budak Kampung dan pengalaman hidup Lat ketika zaman mudanya telah mempengaruhi penciptaan komik Mat Som. Di sebalik semua itu, pertembungan nilai desa dan kota dikesan begitu ketara melalui kemasukan syarikat bijih timah, penjualan tanah, pemilihan jodoh, pemikiran dan gaya pakaian dalam kedua-dua karya tersebut.
\end{abstract}

Kata kunci: komik, pertembungan nilai, sosiobudaya, Budak Kampung, Mat Som

\title{
INTRODUCTION
}

Creative writing has its own special characteristics, such as the writer's language style, emotions and imagination. The four genres in creative writing are the short story, drama, novel and poetry (Othman Puteh, 2002, pp. 5-6). Literature should always be relevant with the times; hence, at present, it 
is not only enjoyed in the conventional printed form, but also online and onscreen via smart phones.

Together with advances in knowledge, comics have a huge potential of becoming the fifth genre in creative writing. Scott McCloud (1993, p. 9), in his book entitled Understanding Comics: The Invisible Art, considers comics as having the potential of becoming a form of literary work similar to other literary forms such as the short story, drama, novel and poetry.

According to McCloud (1993, p. 10), the creation of comics can produce a body of works that bring to light the life, times and worldview of the authors. Comics in fact have a big role in the development of literature other than just being a different creative material from the conventional word-by-word medium. However, comics are still trapped by the wrong perception of often being regarded as light reading material and not qualified to be regarded as literary works. This perception can be disputed because comics and cartoons are no longer considered as cheap reading material and many scholars have since researched and studied the ideas and philosophies behind these works.

In Malaysia, for example, Muliyadi Mahamood, better known as Professor of Cartoons, is the first academician or writer to critically study and analyse cartoons. He is also the first Malaysian to obtain a $\mathrm{PhD}$ in the field of cartoons and is now a lecturer of History and Criticism of Arts in the Faculty of Art and Design, Mara University of Technology (UiTM), Shah Alam. Muliyadi is responsible for carrying out a study of Malaysia's history of cartoons in a factual and academic manner. This documentation indirectly preserves one more national heritage, which can be considered as significant in the production of creative works.

Generally, comics and cartoons are a combination of the art of writing and visual art in producing a story, in addition to being a vibrant art form that is developing rapidly in society (Umbut \& Junuh, 2007, p. 3). Comics and cartoons are often used as a tool to interpret the meaning of a story or message from a political, economic and sociocultural point of view. The messages and lessons in both comics and cartoons are conveyed in a humorous, eerie, sad, angry, happy or spiteful manner. Thus, comics and cartoons are often considered as a humorous and cynical read because the ideas are delivered with the particular intention to criticize and provoke society into rethinking some of the incidents that took place.

According to Umbut and Junuh (2007, pp. 2-3), comics and cartoons have meanings and two traits that are similar; one is storytelling and the other is to tell, portray or present a narrative. Cartoons are a type of drawing 
in the form of representation or symbols that present a statement that is humorous, incisive or sarcastic in nature. Cartoons are normally brief; they are presented in an episode in a panel and evoke questions in readers to think of the cause and effect. Examples of such include the editorial cartoon "Senyum Kambing" published in the special column of the newspaper Utusan Malaysia and the editorial cartoon "Cuit-cuit" in the special column of the newspaper Berita Harian.
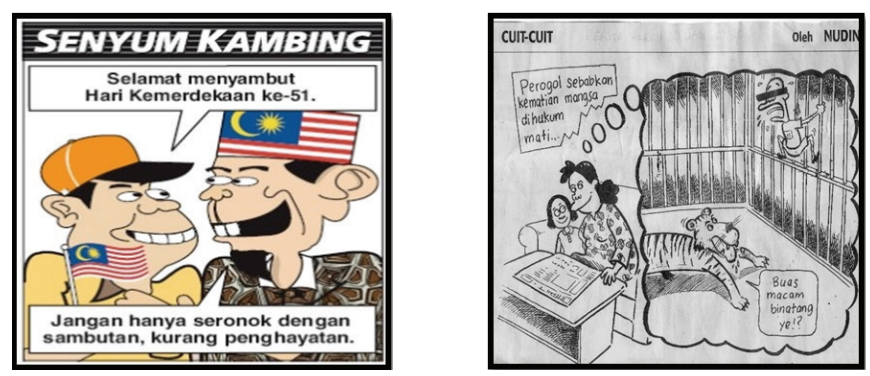

Figure 1 (Left to right) The cartoons "Senyum Kambing" (Utusan Malaysia, August 31, 2008) and "Cuit-cuit" (Berita Harian, January 30, 2004).

Meanwhile, comics are a series of cartoons that use drawings that are arranged to form a longer and more detailed story to convey its message. Typically, comics come in the form of a story in a sequential series. Comics are a very popular reading material among children as well as adults. According to Eisner $(2001$, p. 1), the comic is a form of art or sequential art. According to McCloud (2001, p. 20), comics are pictures or symbols that are arranged in a certain sequence for the purpose of giving information and getting a direct response from readers. Normally, comics are printed on paper and furnished with text and dialogue.

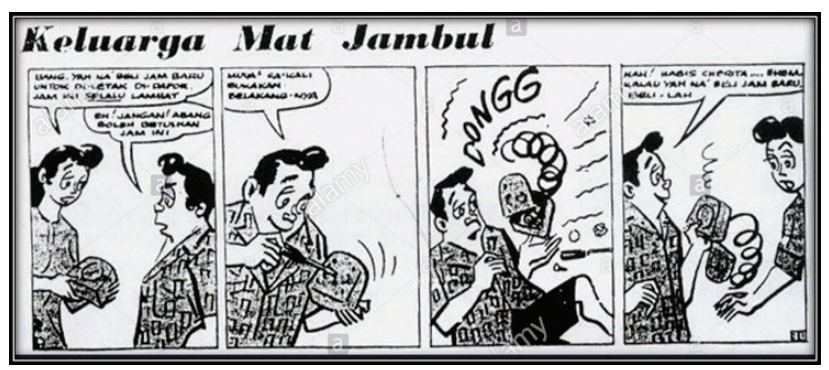

Figure 2 Example of a comic strip in Berita Harian, May 14, 1961. 
Roger Sabin, in his book titled Adults Comics: An Introduction (1993, p. 5), states that the basis of comics is the comic strip. There are several kinds of comics, among them being the comic strip, which is a section of comic comprising several picture panels; this is often published in magazines and newspapers. Comic books are comics that have been compiled into books and are normally in a series. Nowadays, there are digital comics or online comics.

According to Roy Paul Nelson, the idea of a comic strip consists of a concept and involves many people in its production.

For a comic strip, there is, first, the basic idea - or concept - that sends the cartoonist to his drawing board to produce new feature. Typically, a comic strip features an interesting hero - or anti-hero - and several carefully defined supporting characters. The cartoonist producing a comic strip becomes a one-man motion-picture organization: producer, director, writer, art director, cameraman, casting director, costume supervisor - and more. Sometimes the strip represents a collaboration between a writer and an artist.

(Nelson, 1975, p. 93)

The combination of drawings and pictures in comics produces a narrative that is supported by characters, background, plot, theme, issues and lessons. These elements enable comics to be considered as literary works. Apart from presenting a story, comics are able to express a variety of ideas, thoughts or meanings in a symbolic manner, as is the case with any literary work. The

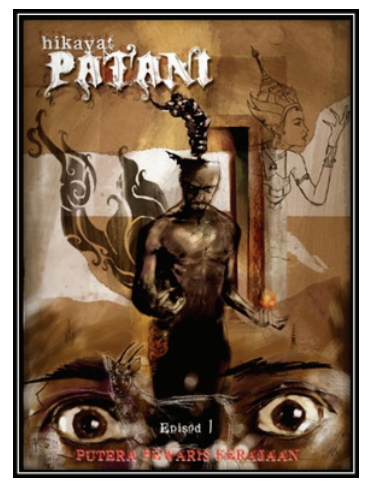

Figure 3 Hikayat Patani, an e-comic published by Dewan Bahasa dan Pustaka 
thinking and ideas are conveyed in various versions, similar to fictional, animal, historical and biographical stories, which are intended to criticize in a humorous manner and teach readers at the same time. Comics play an important role in modern society as one of the mediums for conveying ideas and criticism in the form of satire and humour.

Comics differ from graphic novels. The issues and discussions in a graphic novel are longer, more complex and dense. Comic books are shorter, talk about many issues and are serial stories. Both graphic novels and comics are combinations of illustration and dialogue, relating stories that are fictional and non-fictional. There is no conspicuous difference in content, except in the presentation. A graphic novel revolves around a single story from beginning to end, but most comics are serial stories about many issues or episodes that take place over several months or years. Some comics are successful and later compiled into graphic novels. A graphic novel is in fact a full-blown comic book. The first graphic novel was entitled Lenardo und Blandine and produced in 1783. It was illustrated by Joseph Franzh von Goez, covering 160 panels that tell the story of a pair of star-crossed lovers.

There are several big comic productions that are recognized as influential works and filled with social satire. Among them are The Yellow Kid by Richard F. Outcault, Maus by Art Spiegelman and Krazy Kat by George Herriman.

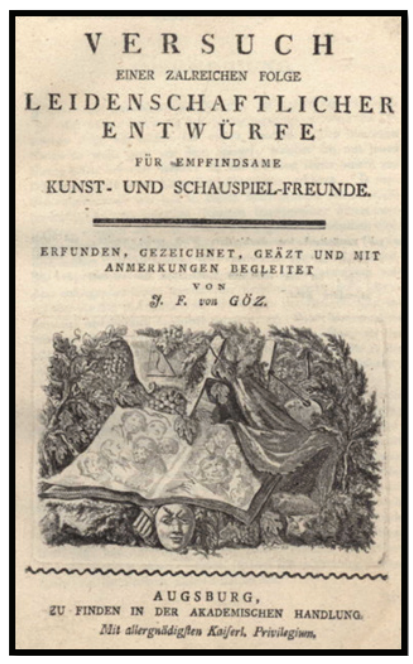

Figure 4 The graphic novel Lenardo und Blandine. Source: Mulder (2001). 
In Malaysia, the first comic was published in 1928 in the Malayan Police Magazine by a local artist named Raja Sulaiman. More comics appeared around 1939 and were published in the paper, Utusan Zaman, through the character of "Wak Ketuk" by Ali Sanat. At that time, the subject of discussion revolved around the issue of the uncontrolled immigration of foreigners, which caused anxiety among the Malays since the number of immigrants began to supersede the Malay population. From 1939 onwards, comics began to attract attention, but the 1980s was the peak of the local comic industry with the emergence of cartoonists such as Rejabhab, Jaafar Taib, Mishar, Zainal Buang Hussein, Lat, Reggie Lee, Imuda, Ujang and Zunar.

Among the cartoonists mentioned, Lat, whose real name is Mohammad Nor bin Khalid, has been a prominent figure and an icon among Malaysian cartoonists since the 1960s. His comics have the potential of becoming a subject for research because his works often touch on controversial national issues, are daring enough to criticize the country's leaders and society and often raise the issue of rural versus urban values. All of Lat's works contain a humorous element, which is a requisite for comics, and upon careful study, his works come across as serious works of art that raise awareness on major issues such as the country's political, social, cultural, societal and economic matters.

Most of Lat's works criticizing the country's leaders and politics have often become the subject of study by local and international scholars. This study is particularly interested in researching the clash of urban and rural values in his selected comics by applying the theory of sociology of literature, which upholds the principle that literary works can become sociocultural documents to observe the milieu of a particular time.

\section{THEORY OF SOCIOLOGY}

The sociological approach began with the philosophical thinking of Auguste Comte (1798-1875), who established sociology as a high-level discipline and worthy of study. His way of thinking received a strong response and influenced other English philosophers. According to Abraham (1973, p. 11):

...the various definitions of sociology as the science of society, of social behaviour which no other discipline can do as well. It is now accepted that history, politics and economics as well as sociology, because they 
all deal with man in society in one way or another, should be called social sciences.

Briefly, the theory of sociology can be summarized as a discipline that intends to study Man's behaviour, the formation of social structure and collective behaviour in the economy, politics, culture and other realms (Durkheim, 1958, pp. 24-27). Sociology is an academic discipline that starts with and involves a reciprocal relationship with society, while sociology of literature starts from the relationship between literature and society. According to A. Rahman Yusof (1988, p. 82), sociology of literature is based on the belief that literature cannot be studied separately from society. In short, literature is not created in a vacuum and is not the product of the author only. In this context, literature is believed to be the product of an author who is defined by space and time and who is responsible to the other members of his society.

Sociology of literature is an approach that starts with the orientation of the author. Literary scholars agree that the father of sociology of literature is Hippolyte Adolphe Taine (1828-1893). Taine, in History of English Literature (1893, p. 19), states that literature is the product of factors such as the race, time and milieu in which the literary piece originates. When a researcher learns about a particular race, time and milieu, then he would understand the idea and thinking of a particular culture that gave birth to an author and his works.

According to Taine, these factors produce the mental structure of an author, who then expresses his thoughts in literature and art. One's nationality or race is related to the psyche, feelings, body shape and the like of a person. Time refers to the sociopolitical and sociocultural situation at a particular time and age. Milieu includes the earth, climate, geography and social condition of the local society or background. Taine's concept regarding milieu attracted the attention of many scholars and researchers because he linked literary criticism with social studies.

As stated by Abrams (1981, p. 178), sociology of literature is used in writings by critics and scholars of literary history with the intention of studying the relationship between the author and social class influence, the society's ideology, the economic situation that is related to the author's career and the type of target readers. According to A. Teeuw (1984, p. 94), literature does not arise from an empty cultural situation; in fact, literary works are imaginative works of fiction. The author attempts to take advantage of a social situation in the society around him as the object and the subject of a literary work. 
According to Ungku Maimunah (2006, p. 3), in the context of Malay literature, generally the concept of sociology of literature is divided into three kinds of premises and application. The first is the assumption that literary texts are free from the demands and influence of the surroundings. Therefore, the study is centred on texts alone and focuses on the effort to highlight the depiction of a fictional society as found in the text studied. This kind of analysis is rather similar to the intrinsic study that only focuses on the depiction of society in the text. The second is analysing the author's surroundings as having an important relationship with the work produced. This study takes into consideration the relationship between a text and its context and how the context influences the content and form of the product. The third is believing strongly that there exists a close relationship between the surroundings and the work produced, upon which the study employs a certain paradigm to examine the problems raised in the literary text. Comparatively, the second premise is far more dominant and forms the discipline of sociology of literature that is followed and practised in studying Malay literature, which is to analyse the author's milieu in relation to his work. An author's milieu includes his education, family, society, philosophy, culture and experience that influence his output.

Alan Swingewood (1988, p. 2) observed two patterns of sociology research using literary data. The first is sociology of literature in which the discussion starts with the social milieu and how literature is linked with external factors in literary works. This type of research looks at the social factors that produce the literary work at a particular time and in a particular society. The second is literary sociology, which links the structure of the work to genre and society. Swingewood's division is shown in the approaches below:

(1) Literary works are seen as sociocultural documents.

(2) Examination of output and marketing of literary works.

(3) Examination of society's acceptance of a writer's work and his purpose.

(4) Sociocultural influence on the creation of literary works.

(5) Genetic structuralism approach by Goldmann.

(6) Duvignaud's approach that sees universal mechanism from art, including literature. 
Out of these six approaches, the researchers chose to apply the sociocultural influence on the creation of literary works in this paper.

\section{SOCIOCULTURAL INFLUENCE ONTHE CREATION OF LITERARY WORKS}

The sociocultural influence on literary work creation is focused on the theory of class conflict based on Marx's theory (Swingewood, 1972, pp. 41-42). Marx's theory is similar to the one developed by Taine, starting from the assumption that literature can be discovered from the source material of a society, which is race, time and milieu. Race is related to the psyche, sentiments, body shape, skin colour and other inherited traits. This concept was popular in the $19^{\text {th }}$ century. According to Swingewood (1972, pp. 31-37), even though milieu can be linked to a certain age - for example, the Middle Ages - it should be limited by climatic and geographical conditions. Thus, the Northern European literature that is filled with bitterness is different from the Southern European literature that is filled with joy. According to Marxism, literature is a reflection of society and is influenced by its historical situation (Eagleton, 1976, p. vi). Every age is faced with the problem of class conflict and the literary output normally expresses the voice of a certain class and becomes a tool in class struggle. However, its influence is greater than simply being about class differences; it also has an impact on form, style and meaning.

This approach sees literature as a super structure with the economic system as its base. The literary output will be the result from the economic system of the society to which the author belongs (Umar Junus, 1986, p. 20). The Marxism approach often uses the historical perspective to understand what took place in the past and thus strives to form a new society that is compatible with their ideological beliefs in two matters. First, regarding the things that have happened, the Marxism approach is descriptive in nature by regarding a work as a result of the awareness of a certain class. Second, it is necessary to study what will happen with the intention of forming a new society.

This approach focuses on text and context to obtain extra information from outside as an addition to the demands of the researcher's enquiry. It thus requires the researcher to make use of the literary text and the information from outside the text. This is because, apart from enjoying the artistic aspect 
of the work, it will also look at the sociocultural influence on the creation of the literary work.

The Marxism approach is criticized because it shows the difficulties in the concept of literature being a social reflection. The critics of Marxist theory are aware that it is impossible to have a classless society. They are of the opinion that the upper classes in society are not something to be opposed but should become the goal of each member of society. Thus, they are inclined to classify authors into two groups: revolutionary authors and reactionary authors. Revolutionary authors fought for the people's rights and opposed dominance by leaders. Reactionary authors opposed what the prevailing reality was because people were embroiled in the capitalist system (Umar Junus, 1986, p. 24).

According to Swingewood (1972, pp. 41-49), the sociocultural influence approach towards literary work creation can be summarized as follows:

(1) Literature is a social reflection.

(2) Social conditions are always marked by class conflict and a writer will be the voice of his class.

(3) The effect of the class conflict will be found in literary works and these writers are the prominent figures who represent their respective class.

Based on the clarification regarding the theory of sociology of literature and the sociocultural influence on literary creations, a work plan can be drawn up to analyse the clash of rural and urban values in Lat's comics Budak Kampung and Mat Som. Out of the six approaches, the researchers found that only the sociocultural influence on the creation of literary works is suitable for analysing the selected two comics for this study.

\section{Budak Kampung (Kampung Boy) (1979) and Mat Som}

Budak Kampung (Kampung Boy) (1979) is Lat's autobiographical work. This comic is a record of his personal stories and experiences when he was a young boy in the middle of Kinta district, Perak, in the 1950s. Briefly, Budak Kampung revolves around Lat's life from the time he was born until the age of ten before he left the village to further his study at a boarding school in the town of Ipoh.

This comic is written from the point of view of the protagonist, or the first person central. He is not given a name and only uses the pronoun "teman" or 
"I" because it is narrated solely through Lat, who is the main character of the comic. "Teman" is the pronoun for the first person in a dialect of Perak that is used in everyday language by Perak folks who live around Kuala Kangsar, Perak Tengah (Central Perak) and Hilir Perak (Lower Perak). This comic does not use a lot of dialogue and, instead, uses description and monologue in the form of text and drawings to convey the story. "Teman" becomes the central focus of consciousness and the centre of the story. Everything that is outside "teman", including incidents, action and people, are narrated only if it is related to the protagonist.

Budak Kampung was originally a piece of work in English entitled The Kampung Boy (1979). According to Lat, in "Bual Bahasa" with the editor of Dewan Bahasa for its July 2008 edition, the idea to produce the comic came about when he returned from the International Visitors Programme sponsored by the United States embassy in 1977 (2008, p. 64). Life in a big city such as Kuala Lumpur, which is always busy and bustling, made Lat homesick and pining for the rural life in his village in Perak. According to Lat, he produced The Kampung Boy in English, thinking that Malaysian society would not be interested in the comic since it was merely stories about rural life and the Malay village culture.

Therefore, Lat targeted The Kampung Boy for the international audience. The target was apt and the comic received an impressive response from them and, at the same time, it also won appreciation from the local society. Since the response was very encouraging, The Kampung Boy was translated into the Malay language and several other languages, such as Arabic, Tamil, Mandarin, French, Dutch, German, Spanish, Italian and Korean, among others. According to The Sun newspaper (2011), this comic was also used as a textbook in primary schools in Australia.

Meanwhile, the comic Mat Som is about a young man from Tanjung Malim, Perak, who migrated to the city to find work. Mat Som works as an independent writer for a newspaper in Kuala Lumpur. His income as a writer at that time is not consistent and his life in the city is a hand-to-mouth existence. Since Mat Som is still young and unmarried, he is not too worried about his situation and quickly adapts to life in the city. However, one day, he receives a letter from his father in the village asking him to marry Wan Faridah, someone he knew from his hometown and is now working in the same city. Mat Som is not ready for marriage. Furthermore, he feels that he should marry someone of his own choosing, but is reluctant to disobey his father. Incidentally, he is also attracted to a girl named Yam, who lives next door. 
Mat Som was published in 1989 and was adapted into a film the following year. It was the first film by Hatta Azad Khan, a director who was a lecturer at the Centre for Creative Industry \& Performing Arts, Universiti Utara Malaya (UUM). The central characters were played by Imuda and Tiara Jacquelina. This was the first Malaysian film adapted from the comic genre and it gained approval from film critics and won the Best Comedy Film and Best Screenplay in 1991 at the 9th Malaysian Film Festival. It was subsequently selected to enter the International Film Festival Tokyo, Hawaii, Bangalore, Fukuoka, Taipei and Jakarta.

\section{SOCIOLOGY OF LITERATURE ANALYSIS ON BUDAK KAMPUNG AND MAT SOM}

Swingewood (1972, pp. 13-14) put forward the concept that literary works can be seen as sociocultural documents that record the sociocultural realities of a society at any one time. This approach sees a one-to-one correspondence between the elements in a piece of work and those of the society, which are depicted through the cultural elements, incidents, images, motifs and themes of that work. This approach starts from the concept of literary work as a reflection of reality.

This can be proven by referring to Budak Kampung, where Lat attempts to revisit his experiences when he was a young boy and explore life in the village. Lat sees life with a sharp mind and an open attitude, but analyses it critically and expresses it through drawings. This comic exhibits Lat's kaleidoscope of childhood experiences. The character that he portrays in fact represents the character of Malaysian society, particularly that of a child growing up in a rural area. The natural characteristics in the drawing of the human character, nature and animals make Lat's comic accessible to many.

Budak Kampung begins with the episode of a child being born and received by the midwife before it is handed over to the village Tok Bilal. This is followed by the giving of gifts in the form of a chicken, yellow glutinous rice and a batik sarong to the midwife. The portrayal continues with the mother ending her confinement, followed by some kampung traditions, such as shaving the baby's head, placing the baby in its hammock and chanting religious greetings to welcome the baby (marhaban). This tradition is the typical practice of a Malay couple who has just had a baby, though such traditions are gradually forgotten by the younger generations.

Typically, this tradition, which is also called berendoi, is carried out after shaving a baby's head on the seventh day of its birth; sometimes, the 
NURUL SYAZWANI MOHD DAHALAN AND WAN HASMAH WAN TEH

ceremony is held on the last day of the mother's confinement period, which is the $44^{\text {th }}$ day since the birth of the baby. This ceremony is held to celebrate the birth of the baby in a family and it is also a way of announcing the birth to the public (mStar , 2013). The ambience during the delivery, the confinement period, the berendoi ceremony, head shaving and marhaban are depicted in the following pictures:
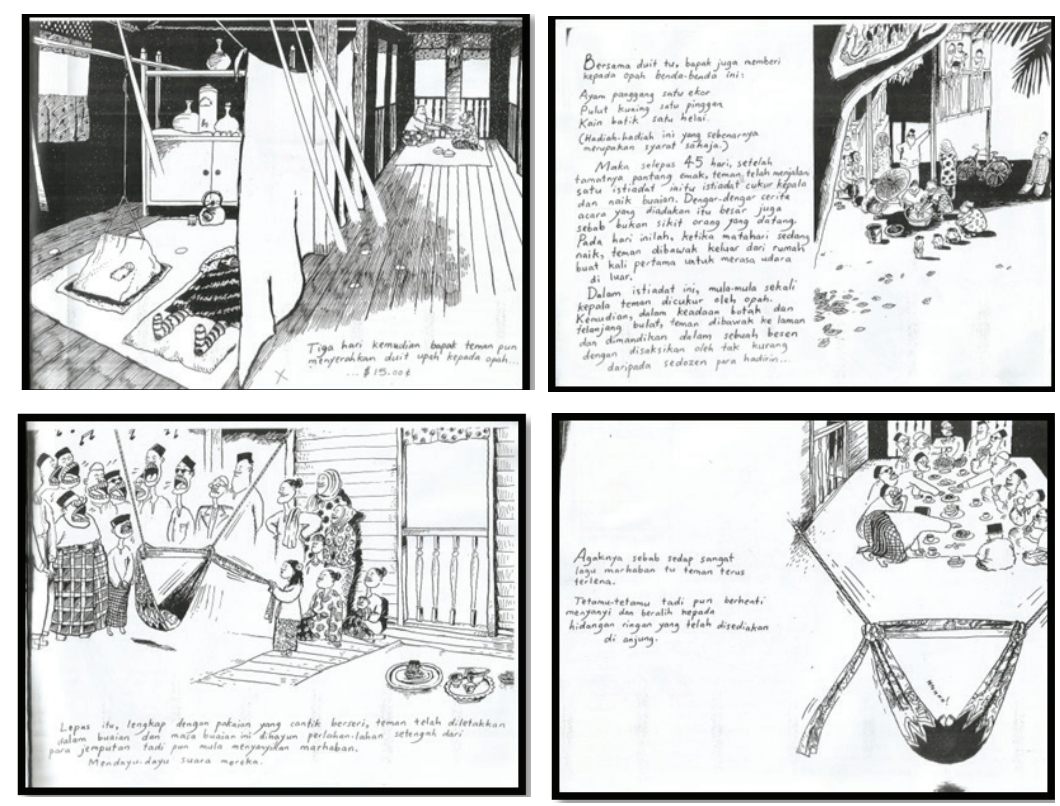

Figure 5 (Clockwise from top left) The ambience during the delivery of baby, confinement period, berendoi ceremony, head shaving and marhaban

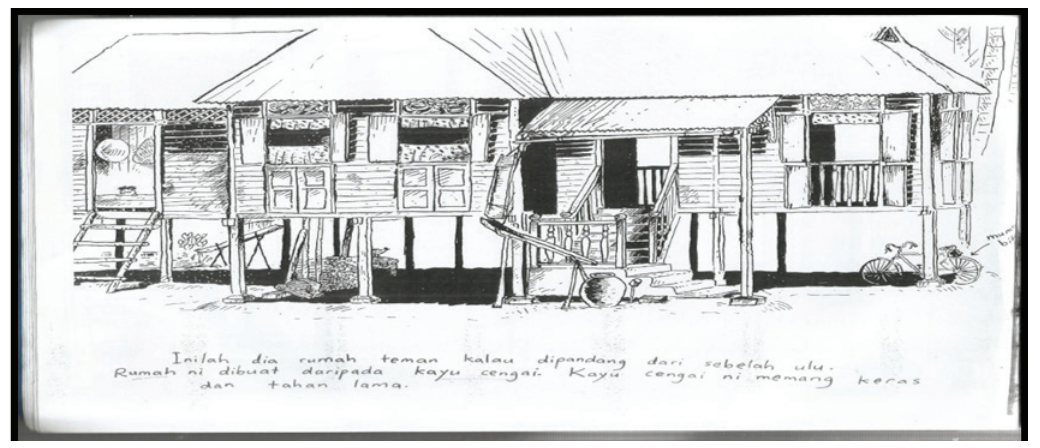

Figure 6 View of "teman's" house from the front. 
Through Budak Kampung, Lat becomes the voice and prominent figure of Malay culture as he is able to portray the various Malay cultural practices to the other races in Malaysia as well as at the international level. Malay culture is highlighted in the traditional Malay house, which is made of cengal wood. As seen in the comic, "teman" describes his house at the time when he is crawling around and starting to explore every nook and corner. The window at the verandah becomes his favourite spot because, at this point, he is still small and is not allowed to climb down or go out of the house by his mother (Lat, 1979, p. 9). He could only see and hear the world outside through that window and this makes him even more curious about the world around his house and village.

When he is four years old, "teman" is allowed to go outside and play in the yard around his house. Even at this early age, he is taught the process of making rubber the traditional way by his aunt, Wan $\mathrm{Cu}$ Khatijah. The process involves pouring formic acid into latex, which is then left for 15 minutes until the latex hardens. To flatten the rubber, it is first stepped on and then fed into a machine (Lat, 1979, pp. 12-14).

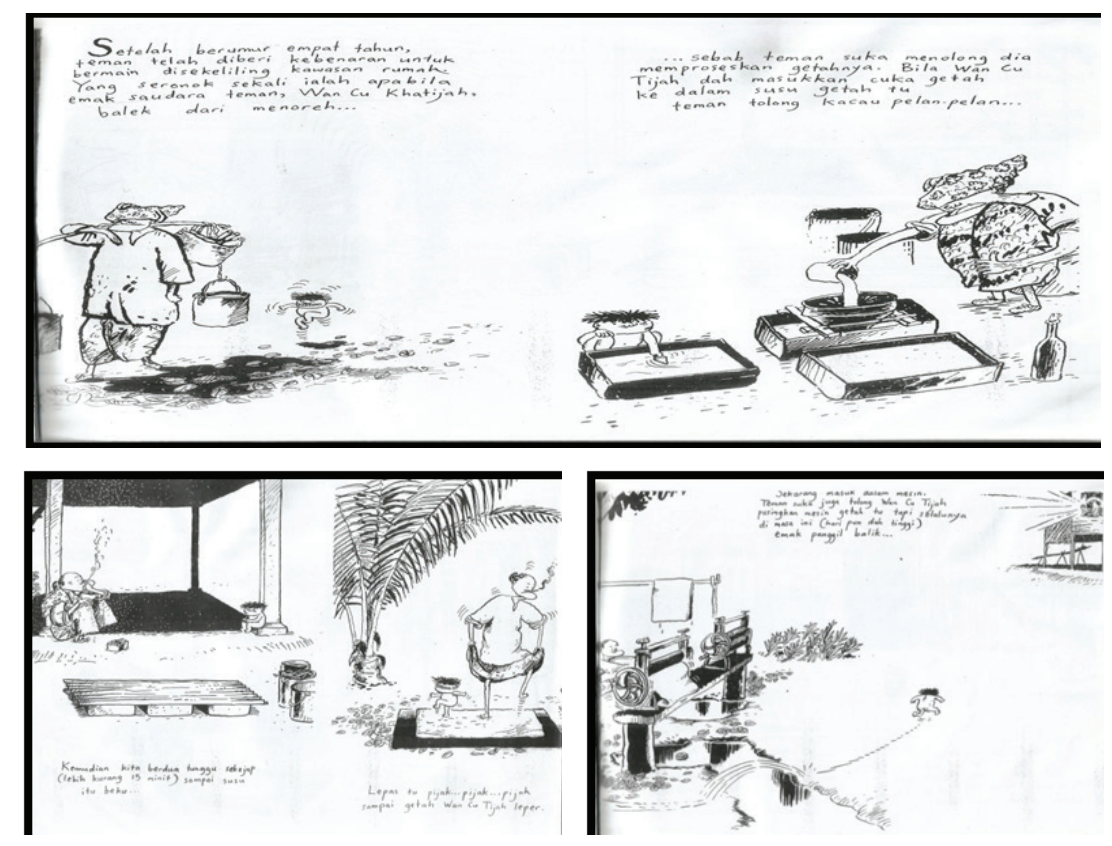

Figure 7 (Counter-clockwise from top) Processing rubber the traditional way by "teman" and Wan $\mathrm{Cu}$ Khatijah. 


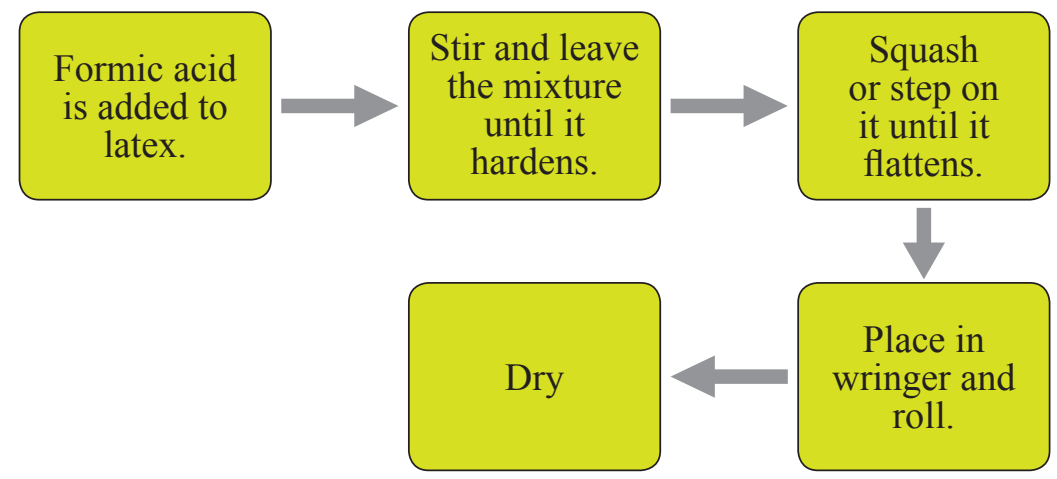

Figure 8 Processing rubber the traditional way.

Natural rubber is the natural product from rubber trees. The liquid extracted from the rubber tree is called latex, which is in liquid form and is sticky. Natural rubber is one of the substances that was used widely by factories to churn out rubber products in the transportation, medical and industrial fields and also in everyday use (Abu Bakar, 1985, p. 424). Unlike the traditional process of making rubber, today's rubber from liquid is processed by using machines to produce sheets of rubber. The modern method can produce rubber sheets that are compact and light and can dry in a shorter time.

This comic also shows the practice of circumcision, which is compulsory for Muslims. Briefly, circumcision is the act of removing the foreskin of a penis in males or removing the edge of the external part of the female genitalia (Sinar Harian, 2011).

In Malaysia, the practice of circumcising a male child is done in a public manner called berkhatan or circumcision ceremony. The rationale is that, in addition to fulfilling a religious commitment, the ceremony is a way of uniting the community. This is highlighted in Budak Kampung. When he is almost ten, "teman" is circumcised alongside his two cousins at his grandmother's house. The comic also tells in detail the practice of circumcision, covering what happens before, during and after circumcision (Lat, 1979, pp. 93-103). Circumcision is now a safer and simpler procedure with a shorter period of recovery. For instance, the smart Klamp procedure is very simple, clean and systematic and is practiced in more than 200 clinics in Malaysia (Sinar Harian, 2011). 

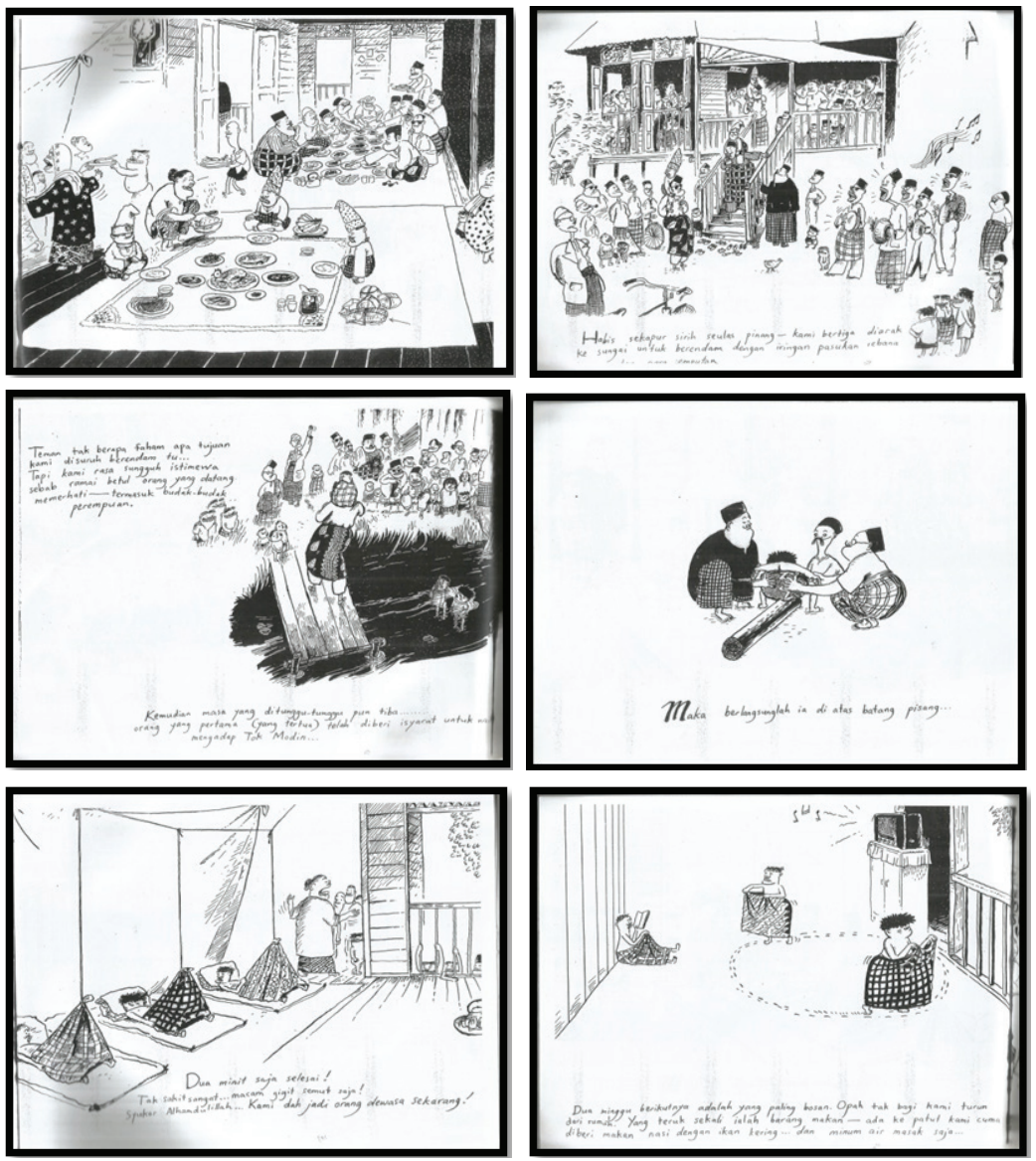

Figure 9 (Row wise) The ambience before, during and after the berkhatan ceremony

This comic also depicts the Malay wedding tradition in villages through a recollection of when "teman" attends a relative's wedding with his family in another village not too far away. The wedding is shown as a merry occasion for the whole day and night at the bride's place. Starting with akad nikah or the solemnization ceremony, the party then moves on to another house for the bersanding (enthronement ceremony for the bride and groom), feasting and bersanding again at night. Lat's exceptional depiction of a Malay wedding evokes the nostalgia of a village wedding, of the groom's large entourage, which required renting cars from individuals who had them, such as the 


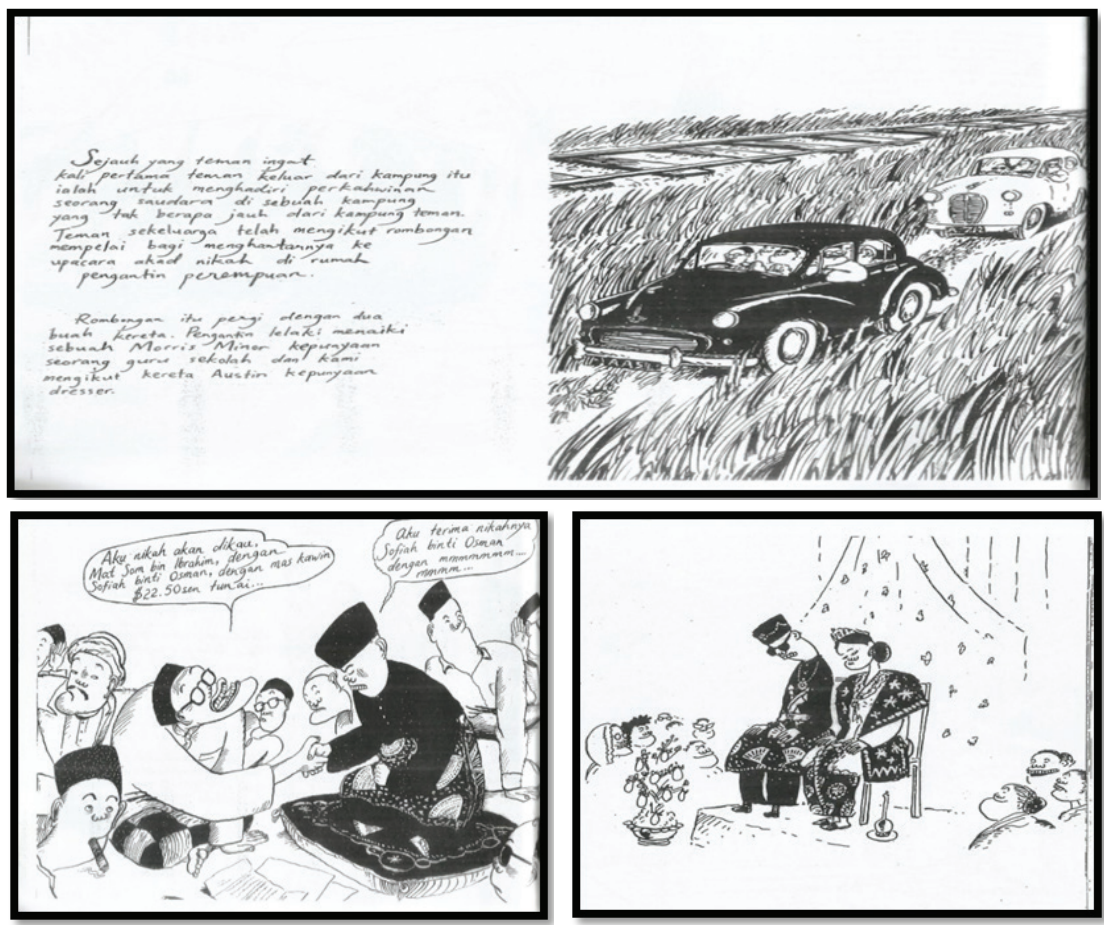

Figure 10 (Top to bottom) Two cars that were rented to ferry the bridegroom's party and the rituals of a Malay wedding.

school teacher and the dresser (Lat, 1979, p. 63). The above are examples of the depiction of the wedding.

As explained earlier, literary works cannot be separated from the milieu or culture in which they are created because they are a mirror of their social reality, as there is a reciprocal relationship between the author, the reader and the milieu. According to Grebstein (1968, pp. 161-169), a literary work cannot be understood comprehensively if it is separated from the milieu or culture that produced it since the ideas in a literary work is as important as the form and technique of the writing.

The sociocultural influence approach on literary creations - which are the social conditions usually marked by class conflict, a writer voicing his class' aspirations as well as the effects of this conflict_-will be found in these literary works. Indirectly, the author is the representative figure for a particular social class. In discussing Lat's comics, class conflict can be seen 
through the clash of values between village and town life because this clash has a huge impact on Lat's creations.

The clash of values in Budak Kampung is depicted through the entry of dredges used for mining tin ore in the kampung area. This in fact was a form of Western imperialism and the colonization and control of local land by foreign powers for economic and political interests. The rapid growth of the tin industry in Malaya, especially in Perak, was linked to the high demand in the world market as a result of the Industrial Revolution in the $19^{\text {th }}$ century in Europe, especially in Britain (Mohd Fikri, 2011, p. 76).

In this context, the clash of values that is explicitly shown was between the tin mining companies and the village communities in the district of Kinta. The mining companies owned by big conglomerates felt that they were a powerful sector that controlled the area. These companies were afforded privileges and heavily guarded to the extent that even when village folks panned for tin ore waste outside the dredges, they were reported to the police.

The impact of imperialist power in the district of Kinta is deeply felt by "teman" even though he is only a ten year old boy. When the headmaster informs him that he has passed the special exam for entry into boarding school, he is so excited to tell his father. However, on reaching home, he sees his father getting into a car with a land broker to go to his father's rubber plantation. His mother tells him that his father intends to sell the land in order to buy a low-cost house in Ipoh. "Teman" is not at all pleased with this plan as he feels that the people would gradually lose the whole kampung.

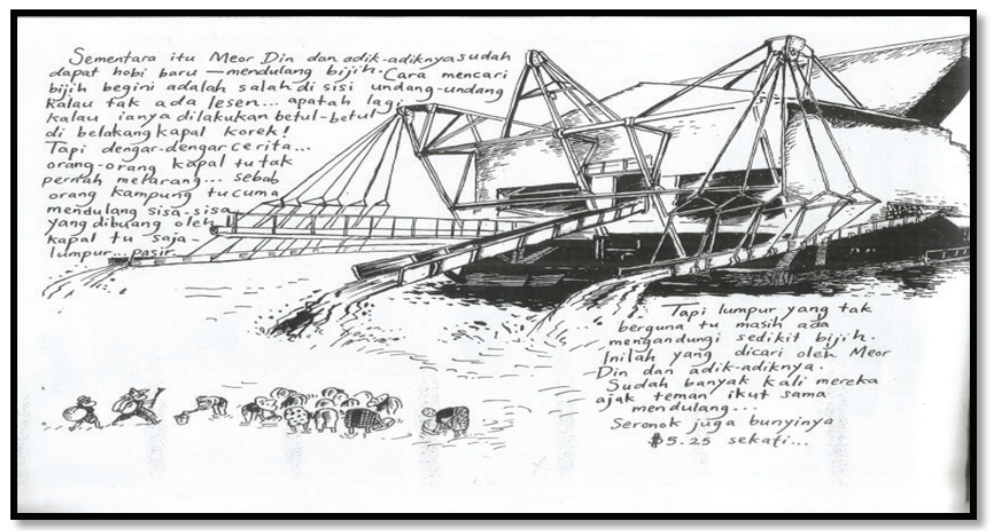

Figure 11 Scene where village folks panned for tin ore waste behind the dredges. 
Through the main character, Lat voiced his stand and hope that the tin ore industrialists would not find tin ore there. Indirectly, he was saying that he hated the situation and was sad that this development would deprive him of his kampung.

This comic indirectly criticized the Malay society who were keen to sell off their land in order to gain temporary wealth and comfort. This phenomenon was caused by the burdens of life, but the impact was so great that some families lost their homes and shelter. Even worse, due to the clash of values, some ended up begging in their own homeland as a result of this mistaken strategy. The advent of imperialism indirectly changed the way of life, economy and political structure of the local society, especially the Malays. Lat was critical of the Malays who were rushing to become city dwellers by abandoning their kampung. They sold their lands in the kampung and attempted to buy houses in the low-cost areas of Ipoh. This is mentioned by the mother of the main character, who was apparently hoping that their rubber plantation would be bought by the broker and that they would be able to buy a low-cost house in Ipoh as the others were doing.

In Malaysia, the diverse races of the population gave rise to different beliefs and ways of life. This had positive and negative outcomes that were related to the emergence of towns as it seemed to have disturbed the status quo of the society. The imbalance between these diverse members of society would further add to the class conflict between those in the villages and cities.

One of the clashes of urban and rural values shown in Budak Kampung is the aspect of development. The particular development identified in the comic is the introduction of dredges in the tin mining areas.

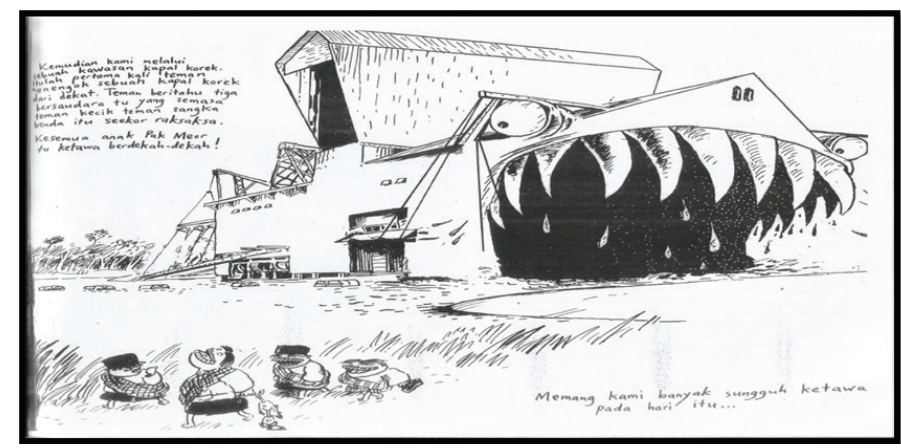

Figure 12 Illustration of the tin dredge in "teman's" village. 
Looking at the illustration closely, the tin dredge is drawn with fangs resembling those of terrifying monsters. This illustration is in fact symbolic of the negative impact of the gradual development and modernization of villages. The background of Budak Kampung is the district of Kinta, Perak, in the 1950s. Perak was rich in minerals following the discovery of tin in the districts of Larut and Kinta in 1848 by Long Jaafar. With this discovery, the economy of the state of Perak flourished and more mining areas were opened (Kerajaan Negeri Perak, 2020).

In the early stages, the mining of tin was controlled by the Malays, but due to British colonization, the British brought in workers from China to escalate the tin mining industry. The implication of this economic development was the emergence of a multiracial society, especially involving the Chinese who came to work in the mines. This phenomenon is highlighted in the comic where the village surroundings are shown to be populated by diverse races, the climax of which is depicted in the last chapter of the comic when "teman" receives the good news that he is accepted into a boarding school in Ipoh.

Development plans do speed up a country's growth. However, if left unmonitored, they will disrupt the ecosystem, leading to disastrous situations. These are some problems that this comic tries to express symbolically. One of the effects of rapid development was the destruction of flora and fauna in the process of preparing the dredging site, which, in turn, disturbed nature's ecosystem. The destruction of flora caused floods and landslides. In addition, there were air, water and noise pollutions during the mining activities, such as explosions and sounds of machinery. This negative impact of development is evident in the earlier part of the comic, where "teman" begins to question what the loud noises were outside the rubber estates.

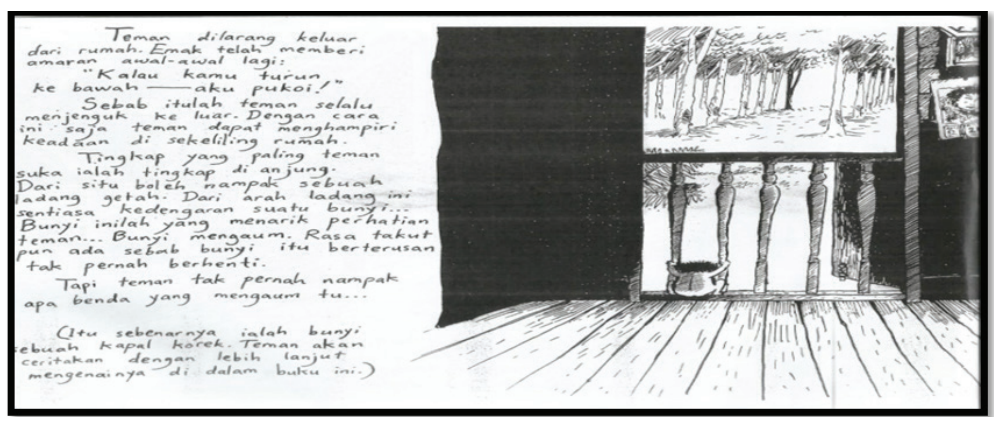

Figure 13 As a child, "teman" is subjected to the continuous roaring sounds from the rubber estates. 
With reference to the sociocultural influence approach on the creation of literary works, the comic Mat Som, which was produced in 1989, revolves around city dwellers and villagers from the perspective of a 28 -year-old young man. In this context, the village society is represented by the people of Tanjung Malim, Perak, whereas city life is represented by the people of Kuala Lumpur. The main character, Mat Som, is in the middle of this clash of village and city cultures. He represents the youths who are trying to adapt to the city while facing dilemmas such as one's responsibility to oneself or one's family. It is a problem that besets Mat Som and the Malaysian society, but it is also a universal issue. The challenges of adapting to a new place, the issue of employment and marriage are experienced by youths in other countries as well. Therefore, this comic is not limited to the local culture only.

The city is a symbol of modernization and globalization. Unconsciously, the race for progress sometimes causes a society to cast aside its culture and traditions, something which the author wants to highlight in this comic. Generally, the younger generation is able to follow modern trends without rejecting Malay culture and traditions, such as their dressing style, speech and traditional beliefs that are still relevant.

According to Zaiton (2004, p. 61), Mat Som is a story about Lat when he started working as a reporter in Kuala Lumpur. If we relate Mat Som's story to Lat's background after he moved to Kuala Lumpur, Lat did apply for a cartoonist job in the newspaper, Berita Harian. However, he was informed there was no available post at that time. Therefore, the editor of Berita Harian, Abdul Samad Ismail (also known as Pak Samad), offered him the post of a crime reporter in this early stage of his career (Lat, 1994, pp. 19-21). The character of Abdul Samad Ismail or Pak Samad is included in Mat Som as proof that this comic has links with Lat's own life in Kuala Lumpur before he became a famous cartoonist. Lat accepted the offer to be a crime reporter as he felt that he needed a job to earn a living. As the eldest child in his family, he was responsible for helping them since his father was seriously ill and incapable of working. This phenomenon is a reality faced by many members of society. Sometimes, due to the burdens of life, youths cannot be too selective about jobs, regardless of what their interests and qualifications are. In fact, they accept whatever offers come their way as a start and consider it as a necessary experience in their life, especially in the city.

Another example of the clash of rural and urban values in Mat Som is the issue of neighbourliness. The prosperity of a country is highly dependent 
on the stability of relations in all social strata, regardless of age, gender, race, religion and culture. This prosperity can be nurtured through close ties between neighbours in the society. However, it is a different scenario in Mat Som. From the very first page, the village community is shown to be very different from the people in towns and cities. The act of introducing oneself to others in the city is not important; in fact, it is something that city folks ignore. The character Mat Som is shown as someone who does not know his next-door neighbour even though they often come across each other while waiting for the bus to go to work (Lat, 1989, p. 15).

Life in a busy town deters its residents from befriending and acknowledging their neighbours. This is in contrast with life in a village, where villagers often carry out activities that foster friendly relationship with each other, such as gotong-royong or working together to clean the village hall, hold feasts and set up a neighbourhood watch to maintain safety and peace.

The spirit of neighbourliness should be born out of the awareness and initiative of individuals. This spirit should be inculcated in the individual and the society because in doing so, problems that crop up can be more easily solved. This attitude is also important in fostering respect and care among neighbours. In this era of globalization, the attitude of self-centredness is becoming more rampant, as portrayed in Mat Som. If this is left to fester, the spirit of neighbourliness will fade away and bring about disharmony in the country.

In the wake of all that development and modernization, a society often forgets the impact it has on the natural environment. Man's greed

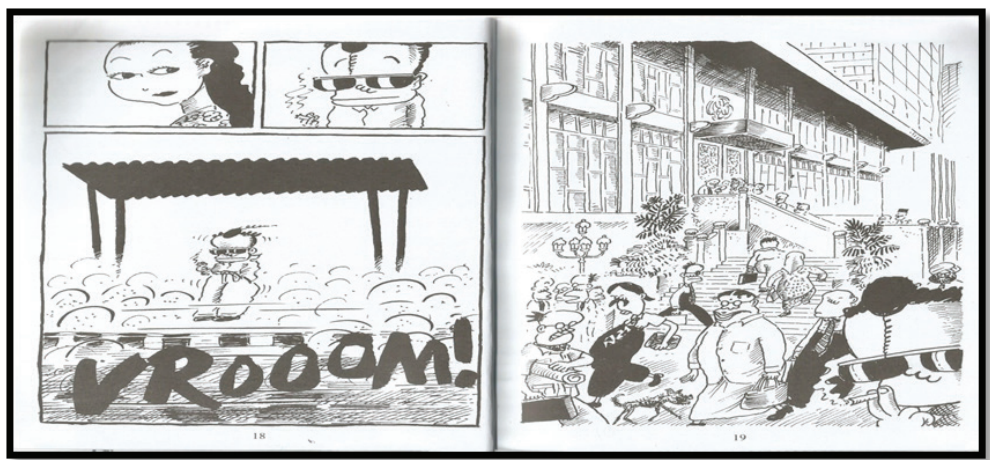

Figure 14 Mat Som's life in Kuala Lumpur, where he never acknowledges his neighbour even though they often come across each other at the bus stop. 
in chasing progress sometimes cause the ecosystem to be disturbed. For example, numerous trees were felled to develop a housing area, to build skyscrapers, roads and other infrastructure. Unplanned development brings about disastrous results, such as landslide, air, water and noise pollutions, flash flood and global warming. For instance, when Mat Som goes out to meet Wan Faridah, it rains heavily in Kuala Lumpur, which causes a flash flood. Many roads became closed and Mat Som has to walk to the place where he has promised to meet Wan Faridah.

The flood situation in Kuala Lumpur becomes so adverse that Mat Som decides to return to his kampung for a while since such floods did not occur there. The ecosystem in the kampung is still maintained because there is not much development or deforestation going on. While this is a depiction of villages around the 1980 s, the situation is different nowadays. The impact of development has led to villages undergoing the process of urbanization, which is the result of Man's desire to be part of the wave of economic development.

Looking at it from a different angle, Mat Som often reminisces about his kampung as if life in the city differs greatly from his own village. Due to the wave of modernization and economic pressures, Mat Som leaves his village to improve his situation. This reflects the overall situation in the 1980s and 1990s in Malaysia. Large-scale migration of village youths to big cities such as Kuala Lumpur took place because of rapid economic growth,
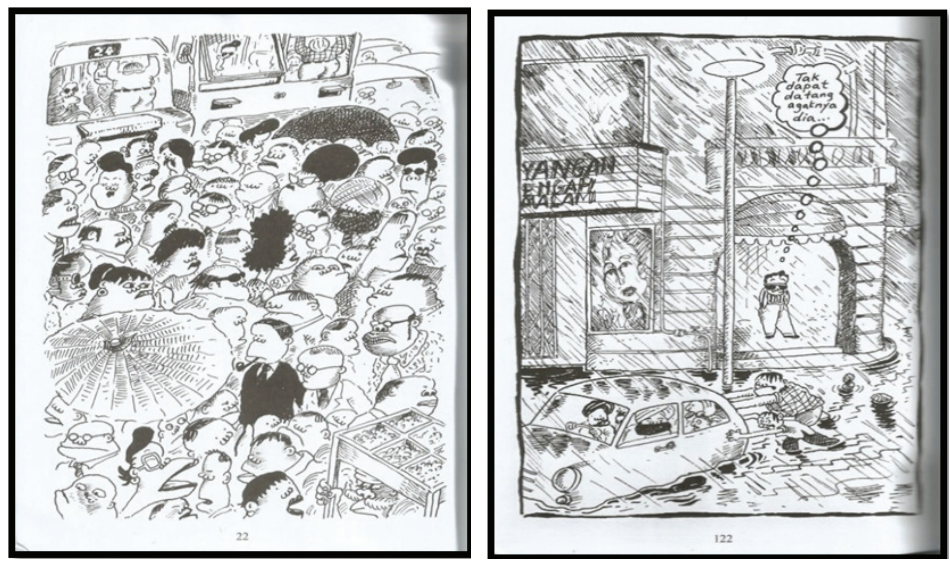

Figure 16 The hustle and bustle of city life in Kuala Lumpur and the flash flood that occurs while Mat Som is waiting to meet Wan Faridah. 
which created opportunities for jobs and good pay (Nor Ermawati, Norehan \& Hussain, 2015, p. 121).

Based on a study by The Statistics Department, Malaysia, there are three main reasons for migration related to employment. These are change of place of employment or starting a new job, looking for work and resigning or retiring (Statistics Department Report, 2010). Population migration is important as it contributes to one of the factors that influence urbanization and development of a country. This migration phenomenon is the main factor that contributes to the economic growth of a country.

Many factors such as education, marriage, job opportunities and geographical factors cause people to migrate (Nor Ermawati, Norehan and Hussain, 2015, p. 122). It is the same case for Mat Som, who migrates to Kuala Lumpur to look for work and start a better life. Mat Som in fact represents the youths who experience the dilemma of age, responsibility and the future. Mat Som also brings the readers back to his life in the village and his childhood days. At the same time, the comic reveals the social and cultural conflicts that are spreading in society.

According to Han Xiao @ Indah (2016, p. 246), one of the causes of migration from villages to towns is the advent of modern society and the process of transformation from the traditional to the modern. Since the 1970s, the government started to emphasize on a more rapid industrial growth to create more jobs and carry out the New Economic Policy. At the same time, in order to reduce the economic imbalance between the races, especially between the Malays and Chinese, the government encouraged the Malays to migrate to towns to earn a living and improve their situation. From the very beginning, the life and behaviour of the Malays in urban areas underwent drastic changes compared to the life of their parents who lived in the rural areas. This situation also influenced the lifestyle, way of thinking, jobs and marriage matters for both town and village societies. All these situations are depicted vividly in Mat Som, one example being the clash of rural and urban values in the matter of choosing a suitable marriage partner.

In the comic, Mat Som is depicted as a 28-year-old young man who does not have a regular job and stays at So'ud's house out of his friend's goodwill. In fact, Mat Som is also portrayed as a person who was often in debt. His situation is not known to his parents in the village. His father, Mat Top, is of the impression that Mat Som has a good salary working as a writer. Thus, his father comes up with the idea of matchmaking his son with his friend's daughter, Wan Faridah Haji Aladin. When Mat Som returns to the 
village, his father asks him to come along to the barber shop. Typical for a father, Mat Top proudly introduces his son to his friends and speaks of Mat Som's job, thinking that the latter has a successful career in Kuala Lumpur.

This is actually far from reality because Mat Som is struggling to adapt himself and is looking for a permanent job in Kuala Lumpur. The clash of rural and urban values is clearly evident here as Mat Som believes that he has the right to choose his future spouse. There is definitely a clash of values between tradition and modernity as Mat Som, being young and modern, has his own ideas about whom to marry while his father, Mat Top, who is from the typical Malay society, wants his son to marry the daughter of his own friend (Lat, 1989, pp. 163-165). This clash of values finally ends in an argument between Mat Som and Mat Top. Mat Som expresses the hopes and aspirations he wants to achieve before settling down. This naturally upsets Mat Top, who thinks that Mat Som is trying to teach him about life instead. Although Mat Som is really opposed to Mat Top's stand and principles, he agrees to his father's wishes as the traditional values of his kampung are deeply ingrained in him.

Through the stories of city life in Mat Som, we are shown how individuals undergo some form of identity crisis when trying to adapt to the urban way of life. The character who is most obviously undergoing this in Mat Som is Wan

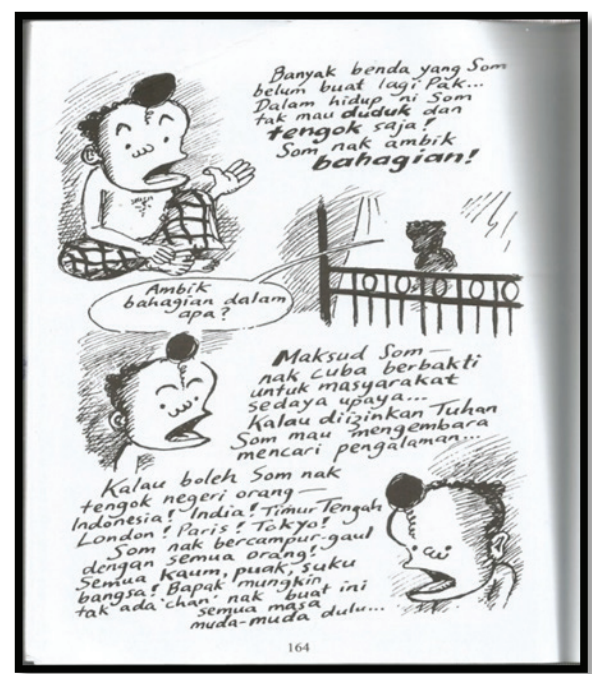

Figure 17 Argument between Mat Som and Mat Top on life choices and principles, especially regarding choosing a spouse. 

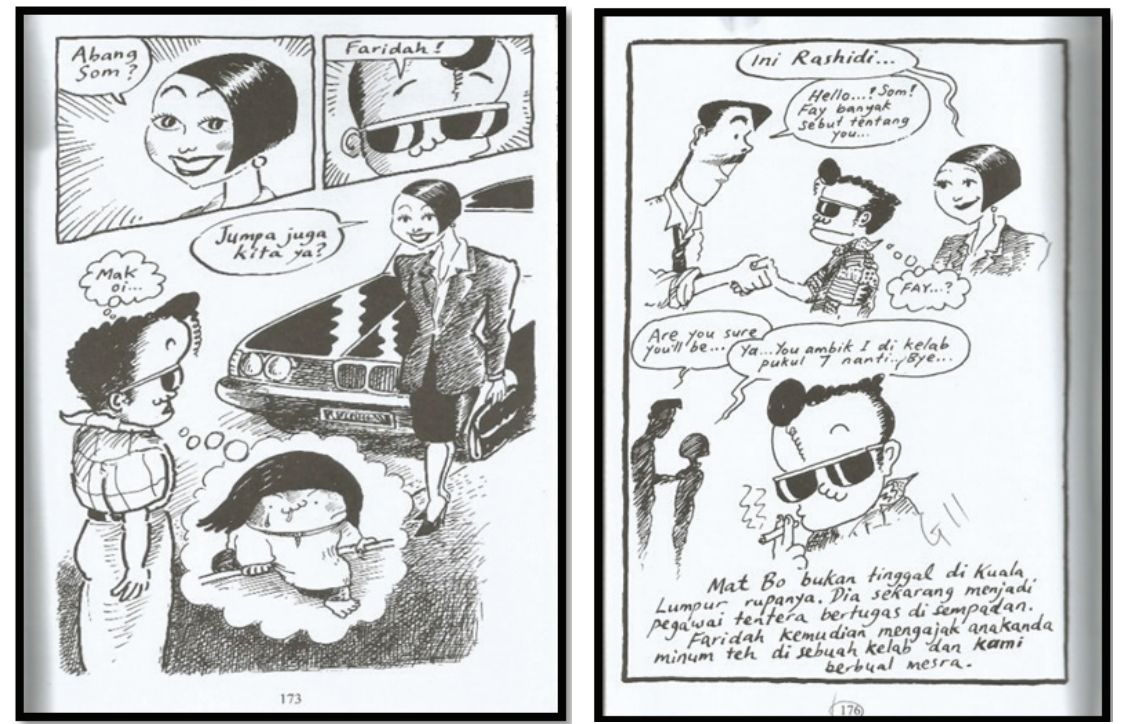

Figure 18 (Left to right) First meeting between Mat Som and Wan Faridah, who brought along her friend, Rashid.

Faridah. She is Mat Top's choice of bride for Mat Som. The contents of his letter reveals the positive aspects of Haji Aladin's family, which convinces Mat Top that Wan Faridah was the most suitable choice for a wife.

However, when Mat Som meets Wan Faridah, the latter's personality is different from the one he remembers as a child. Wan Faridah looks like she is comfortable assimilating to the surroundings of Kuala Lumpur. Her style of clothing and speech are very modern and Westernized; the fact that her nickname is Fay indicates how modern she has become. Nevertheless, Wan Faridah still retains her Eastern values, such as her politeness, friendliness and humility. In the matter of marriage, Wan Faridah has the same stand as Mat Som, which is they should marry someone of their own choice. Han Xiao@ Indah has discussed about these drastic changes that took place in the way of thinking and marriage issues when the Malays started to migrate to towns (2016, p. 246).

Two drastic changes that take place in the character of Yam are her style of clothing and way of thinking. In the beginning of the story, Yam is often dressed in a kebaya at her workplace. However, at the end of the story, Yam's clothing changes to a modern style, complete with the rock culture image, when she attends a concert in the heart of Kuala Lumpur. This style of 


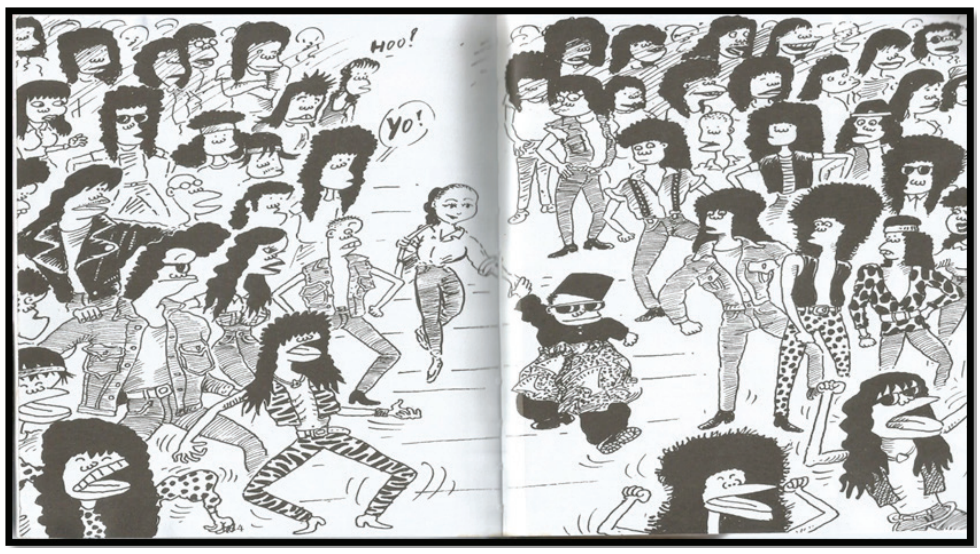

Figure 19 Mat Som's style of clothing is different from Yam's and the others around him while attending a rock music performance.

clothing is entirely different from Mat Som's, who wears a traditional Malay attire as he has just returned from the wedding feast of his friend, Leman.

Looking back at the 1980s, Western rock music was then at its peak in Malaysia, giving rise to the formation of local rock groups. This phenomenon flourished with the holding of competitions such as "Juara Rock", "Festival Rock", "Battle of the Bands 1 \& 2", "Clash of the Bands", "War Rock 1 to 4" and others. The rock music trend in this decade was so popular that it influenced the style of clothing and speech, and to the extent that young folks began keeping long hair, which was a unique symbol of rock identity at that time. The appearance of rock groups with long hair caused outrage among the general public and drove the government to limit their "unsuitable" appearances in government-sponsored media channels beginning in 1998 (Saharudin, Utusan Malaysia, 2002).

The comic Mat Som is in fact symbolic, as it criticizes the Malays who have lost their identity after moving to towns. In the process of advancement, which involves rapid changes, especially due to pressures from foreign cultures and globalization, members of the society face the problem of upholding their traditions, culture and identity. The society is rushing to advance themselves and be at par with Westerners in terms of modernization, thus sacrificing their identity and noble values. In facing these challenges, the elements of traditional culture are cast aside and the modern lifestyle is adopted. On the last page of this comic, Lat states his personal views about the clash of 


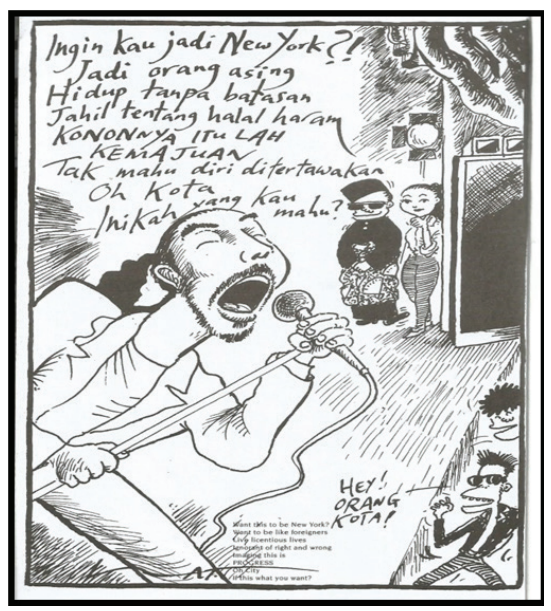

Figure 20 Lat's criticisms are expressed by a singer and witnessed by Mat Som.

rural and urban values as well as the rapid pace of development that causes Malaysian society to lose their identity, as illustrated in the Figure 20.

The irony here is that the criticism is expressed by a rock singer, showing that Lat purposely wanted to create awareness in his readers and, at the same time, criticize the young who are swayed by the trendy rock entertainment and do not realize that a drastic change has taken place in themselves. His comments question the progress achieved by the country and its people.

\section{CONCLUSION}

Through the comics Budak Kampung and Mat Som, this study finds that the sociology of literature theory, which highlights the sociocultural influence in the creation of literary work, is an appropriate benchmark to observe the clash of rural and urban values. This study has provided the current sociocultural interpretation and situation that influence both these comics. Both comics depict the lifestyle and manners of the Malay society around the 1950s and 1960s. In Malaysia, the diversity of the population gave rise to a variety of cultures that shape the people's beliefs and practices. However, in this aspect, the study's discussion is confined to the Malay culture and the crises that resulted from rapid development and progress. The Malay culture prioritizes the values of good manners, moderation, beauty and harmony in life among members of the family and neighbours. Development and 
progress cause the local society to gradually lose their local identity and moral values. For example, as a result of progress, the character "teman" loses his village hometown, whereas Mat Som becomes the young man who answers the country's call to migrate to towns in order to change his luck and the economy of the family. Based on the discussion of these issues, the clash of values between the village and the city in the comics Budak Kampung and Mat Som have been carefully analysed through the characters and incidents found in these two works.

\section{REFERENCES}

A. Rahman Yusof. (1988). Sosiologi Sastera dan Penelitian Kesusasteraan Malaysia. In Hamzah Hamdani (ed.), Konsep dan Pendekatan Sastera. Kuala Lumpur: Dewan Bahasa dan Pustaka.

A. Teeuw. (1984). Sastra dan Ilmu Sastra: Pengantar Teori Sastra. Jakarta: Dunia Pustaka Jaya.

Abrams, M. H. (1981). A Glossary of Literary Terms. New York: Hot, Rinehart and Winston.

Abraham, J. H. (1973). The Origins and Growth of Sociology. Middlesex: Penguin Books Ltd.

Abu Bakar Haji Ahmad. (1985). Teknologi Getah Asli. Kuala Lumpur: Institusi Penyelidikan Getah Malaysia.

Ahmad Rashidi Hasan. (2001). Sejarah Seni Lukis. Shah Alam: Karisma Publications Sdn. Bhd.

Ahmad Shazwan Md. Yusof. (2018, February 28). Kampung Boy bakal difilemkan - Lat. Utusan Online. Retrieved on 17 May 2018 from http://m.utusan.com. $\mathrm{my} / \mathrm{berita/nasional/video-kampung-boy-bakal-difilemkan-lat-1.618161}$

Anwar Ridhwan (Penulis Skrip). Faizal Jalil (Pelukis Ilustrasi). (2014). Hikayat Patani: Putera Pewaris Pemerintahan (Episod 1). e-Komik. Kuala Lumpur: Dewan Bahasa dan Pustaka.

Durkheim, Emile. (1958). Key Sociologists. In Ken Thompson (ed.). London and New York: Routledge.

Eagleton, Terry. (1976). Marxism and Literary Criticism. Berkeley: University of California Press.

Eisner, Will. (2001). Comics and Sequential Art. Tamarac, FL, U.S.A.: Poorhouse Press.

Grebstein, Shedon Norman. 1968. Perspectives in Contemporary Criticism: A Collection of Recent Essays. New York: Harper \& Row.

HanXiao@ Indah. (2016). Pemodenan dan Pembentukan Keluarga Melayu di Bandar. Melayu: Jurnal Antarabangsa Dunia Melayu, 9(2), 245-261. 
Kerajaan Negeri Perak, (2011). Retrieved from https://www.perak.gov.my/index. php/kerajaan-negeri/info-umum/sejarah-ringkas

Lat. (1994). Budak Kampung. Kuala Lumpur: Berita Publishing Sdn Bhd.

Laurenson, Diana T. \& Swingewood, Alan. (1972). Sociology of Literature. New York: Schocken Books Inc.

McCloud, Scott. (1993). Understanding Comics: The Invisible Art. New York: HarperCollins Publisher.

McCloud, Scott. (2000). Reinventing Comics. New York: HarperCollins Publisher. Mohammad Nor Mohd Khalid. (1989). Mat Som. Petaling Jaya: Kampung Boy Sdn. Bhd.

Mohd Fikri Che Hussain. (2011). Awas Ancaman Orientalis kepada Kita. Selangor: Grup Buku Karangkraf.

Mulder, M. (2011, September 30). Lenardo und Blandine, illustrated by Joseph Franz von Goez (1783). Retrieved from https://zsr.wfu.edu/2011/lenardo-undblandine-illustrated-by-joseph-franz-von-goez-1783/

Nelson, Roy Paul. (1975). Cartooning. Chicago: Henry Regnery Company.

Nor Ermawati Hussain, Norehan Abdullah \& Hussain Abdullah. (2015). Hubungan Migrasi Dalaman dengan Faktor-faktor Penarik: Kajian Kes di Malaysia. Jurnal Ekonomi Malaysia, 49(2), 121-133.

Othman Puteh. (2002). Tip \& Motivasi. Penulisan Genre Cerpen. Kuala Lumpur: Utusan Publications \& Distributors Sdn. Bhd.

Sabin, Roger. (1993). Adult Comics: An Introduction. London: Routledge.

Swingewood, Alan. (1988). A Short History of Sociological Thought. London: Macmillan.

Taine, Hippolyte A. (1872). History of English Literature. Translated by H. Van Laun. Edinburgh: Esmonston and Duglas.

Umar Junus. (1986). Sosiologi Sastera: Persoalan Teori dan Metode. Kuala Lumpur: Dewan Bahasa dan Pustaka, Kementerian Pelajaran Malaysia.

Umbut \& Junuh. (2007). Teknik Melukis Kartun \& Komik. Kuala Lumpur: PTS Millennia Sdn. Bhd.

Ungku Maimunah. (Julai 2006). Pemahaman dan Penerapan Sosiologi Sastera dalam Sastera Melayu Moden. Akademika, 69, 3-16.

Zaiton Abu Samah. (Februari 2004). Lat Menawan Hati dengan Lakaran Kartun. Dewan Masyarakat.

Received: 18 June 2020

Accepted: 11 August 2020 